\title{
nature
}

\section{How to respond to Mr Andropov}

\section{President Reagan has listened to Mr Andropov (not before time) and is sending his vice-president to Europe. What follows is a check-list for Mr George Bush.}

THE Reagan Administration seems finally to have heard what $\mathrm{Mr}$ Yurii Andropov is saying about opportunities for agreements on arms control: last week's remarkable declaration of the Warsaw Pact members in Prague can have given it very little choice. Whether it is an adequate response to send Mr George Bush, the Vice-President, on a fact-finding tour of European capitals is another matter; vice-presidents are usually listened to more attentively abroad than they are in Washington. But in case $\mathrm{Mr}$ Bush needs help of a kind that the State Department may not provide (and Nature, makes no apology for its continuing interest in this corner of the political woods to which technology has a unique contribution to make), what follows is a simple guide to what $\mathrm{Mr}$ Andropov has been saying.

- Who is for peace? Everybody. So much can be told by comparing last week's long (and sometimes repetitive) declaration from Prague with the much more laconic declaration on arms control put out after the meeting of the North Atlantic Treaty Organization (NATO) in Bonn on 10 June last year, with President Reagan in attendance. Both documents emphasize the dangers in the accumulation of military arms in Europe and urge the need for "stable" (NATO) or "equitable" (Warsaw Pact) treaties to limit these at lower levels. Over the past few months, Western governments, singly or collectively, have been responsible for almost as many proposals for measures of arms control as are to be found in the Prague Declaration. President Reagan himself has been responsible for two important proposals - the "zero option" on intermediate nuclear missiles and the suggested reduction of 50 per cent in strategic missiles (compared with $\mathrm{Mr}$ Andropov's 25 per cent). The chief difference is that the Warsaw Pact countries keep saying that they are for agreement even when they are only half serious, but that NATO members (perhaps hamstrung by domestic diffidence in the United States) fail to say as much and thus lose the initiative to the East and to those legitimate domestic pressure groups campaigning against nuclear weapons.

- What can be done quickly? The simplest course would be to ratify two forgotten treaties - the Threshold Test-Ban Treaty (1974), which would require the Soviet Union and the United Sates to provide each other with seismic data invaluable for the continued monitoring of underground explosions, and that regulating peaceful nuclear explosions (1976), which for the first time admits of mutual inspection of the sites of nuclear explosions. It is pointless that these treaties should have been signed, and that the two parties should behave as if they were binding, while the positive technical benefits are denied. On the other hand, attempts at the ratification of Salt II would at this stage be counterproductive.

- What comes after? The Prague declaration contains at least 21 specific proposals for East-West agreements including several on which encouraging progress has recently been made. One of the best bets is for a treaty to prohibit the use of chemical weapons, being negotiated at the Geneva Committee on Disarmament. The comprehensive test-ban treaty (also now with the Committee on Disarmament since trilateral negotiations were abandoned in November 1980) includes valuable provisions on international inspection but is probably, at least for the US Senate, dependent on an agreement on strategic arms (now called START). The urgent need for 1983, however, is an agreement on intermediate- range weapons in Europe, if only because the cruise and Pershing II missiles are due to be installed by the end of the year. The Prague declaration is mistaken in asserting that the West has imposed an "artificial deadline" on these bilateral negotiations, giving itself immunity from the effects of procrastination - no West European government would agree. But the British and French nuclear weapons will have sooner or later to be counted either as intermediate or strategic weapons, one reason why both sets of bilateral negotiations at Geneva must soon be merged.

- What can wait, at least temporarily? The Prague declaration is confusing in its completeness. Nuclear-free zones in Northern Europe and in the Balkans, desirable (but tricky) though they would no doubt be, are by precedent and principle matters for the states concerned. The proposed non-aggression treaty is in much the same case: but the West will sooner or later have to explain why its pragmatic way of conducting international relations persuades it to behave as if such treaties were not worth much.

- What are the unexpected opportunities? The Prague declaration contains two elements that $\mathrm{Mr}$ Bush should recognize as important - a ringing declaration that the reduction of conventional forces in Central Europe is also important, and a statement that a concerted policy on the supply of nuclear equipment and materials would be of powerful assistance in the restraint of the spread of nuclear weapons. The first proposal anticipates the intention of West European governments, the British chief among them, to revivify the MBFR (for mutually balanced force reduction) talks in Vienna, the longest running diplomatic show on earth, by presenting it with a draft treaty; the second is a splendid chance to make explicit the tacit understanding between the nuclear powers that they will keep their club as small as possible. There is also, on the strictly political plane, much to be said for the notion of a meeting between the governments of NATO and the Warsaw Pact.

- What about the politics? The Prague declaration is eloquent about the need that the Madrid conference on the Helsinki agreements, soon to reconvene, should do something substantial to strengthen the exchange of information, military and otherwise, helping to build confidence of one side in the other: that is an an opportunity. The Prague and Bonn documents differ, however, on what they say about third parties - the Warsaw Pact insists that Western states should not assume the right to interfere in the affairs of third parties, the Bonn declaration that human rights become an issue wherever they are subverted by outsiders (Afghanistan, Poland). In reality, however, the disagreement is not as sharp as Mr Bush may think, and he should report in those terms when he gets back to Washington. He should also then describe in some detail the confusion that persists in Western Europe about his superior's wish to make the export of high technology to the Soviet Union impossible. The Prague declaration includes a long passage extolling the virtues of economic collaboration and social intercourse in Central Europe (incidentally offering to disband the Warsaw Pact if only NATO would agree to go out of business, which is a potentially poisoned chalice). The terms in which this is done would strike a responsive chord among those in Western Europe able to read them. Mr Bush will be hard-pressed, while making his rounds, to live up to that. He will have no choice but to do his best. 